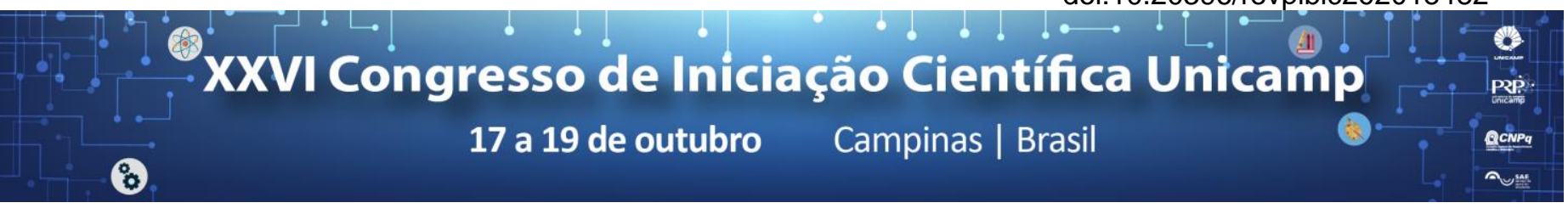

\title{
ENSINO DA CAPOEIRA POR MESTRES E PROFESSORES DE CAPOEIRA
}

\section{Gabriel de Moraes Ventura*, Eliana de Toledo.}

\section{Resumo}

O ensino da Capoeira, tem como característica principal a transmissão de conhecimento do mestre para o aluno pela oralidade. O objetivo dessa pesquisa foi diagnosticar e analisar quais são as formas de ensinar Capoeira, por mestres, professores Capoeira. Para realização da pesquisa foram realizadas entrevistas abertas com oito voluntários com pelo menos 5 anos de experiência de ensino da Capoeira. Como metodologia adotou-se a análise de conteúdo, aplicada aos depoimentos transcritos coletados. Os resultados, nos mostram que métodos tradicionais vêm sendo renovados e combinados com metodologias contemporâneas à prática. Os profissionais da Capoeira e seus respectivos grupos parecem estar mais receptivos a novas metodologias e a renovações de seus métodos tradicionais.

\section{Palavras-chave:}

Capoeira, Método de Ensino, Pedagogia do esporte.

\section{Introdução}

O ensino da Capoeira, tem como característica principal a transmissão de conhecimento do mestre para o aluno pela oralidade ${ }^{1}$. O principal objetivo dessa pesquisa foi diagnosticar e analisar quais são as formas de ensinar a Capoeira, por mestres, contramestres professores de Capoeira, fazendo um paralelo aos métodos encontrados na literatura em uma pesquisa PIBIC anterior.

O objetivo específico foi comparar dois perfis distintos de profissionais de Capoeira: formados em Educação Física e/ou Esportes e profissionais sem essa formação. As coletas das entrevistas foram realizadas com três mestres, três contramestres e dois professores de Capoeira. Como metodologia adotou-se a análise de conteúdo, aplicada aos depoimentos transcritos coletados em entrevista aberta².

\section{Resultados e Discussão}

Tabela 1. Metodologia de ensino de profissionais da capoeira, formados e não formados.

\begin{tabular}{|c|c|c|}
\hline Método & Formados & $\begin{array}{l}\text { Não } \\
\text { formados }\end{array}$ \\
\hline Método de sequências & 1 & 2 \\
\hline Musicalidade & 3 & 1 \\
\hline Método aberto & 1 & |------------------ \\
\hline Método fechado & 1 & 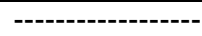 \\
\hline Capacitação em duplas & 2 & 2 \\
\hline Capacitação individual & 2 & |----------------- \\
\hline Capacitação em roda & 1 & ------------------- \\
\hline Contação de histórias & 1 & ----------------- \\
\hline Exploração & 1 & ------------------ \\
\hline Resolução de problemas & 1 & 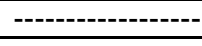 \\
\hline Métodos combinados & 1 & ----------------- \\
\hline $\begin{array}{lll}\text { Capoeira } & \text { para } & \text { grupos } \\
\text { especiais } & & \\
\end{array}$ & 1 & --------------- \\
\hline Jogos e brincadeiras & 1 & 1 \\
\hline Centrado no aluno & 1 & 1 \\
\hline Diretrizes essenciais & 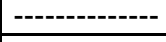 & 2 \\
\hline Valores e virtudes & ------------ & 3 \\
\hline Ensinar pegando na mão & ------------ & 1 \\
\hline Total & 14 & 9 \\
\hline
\end{tabular}

- F4:"Aí geralmente eu faço uma hora e meia de aula é uma hora de parte física e meia hora de instrumento no começo eu armava o berimbau, agora também não armo mais para ninguém, para eles poderem não ficarem acomodados também"

- $\quad N F 3: " A$ gente tem uma metodologia de ensino que trabalha com algumas sequências: Sequências de Esquiva, sequências de golpes sequências de aú [...]" Em sua maioria os profissionais ensinam a musicalidade, isso está claramente relacionado à essência da capoeira enquanto prática de jogo, luta e dança. Métodos tradicionais a prática como o uso de sequências e a capacitação em dupla, aparecem em destaque na fala dos entrevistados, no entanto, a utilização de sequências, não se limita às oito sequências clássicas de Bimba. Métodos contemporâneos à prática como, resolução de problemas, centrada no aluno, e através de jogos e brincadeiras aparecem nas falas da maioria dos voluntários formados em Educação Física.

Ao olhar para a tabela 1, é possível também observar uma diversidade maior de métodos utilizados pelos profissionais formados em Educação Física.

\section{Conclusões}

Os métodos tradicionais da Capoeira, como o uso de sequências, estão passando por renovações e combinações com métodos contemporâneos à prática. Isso demonstra que, apesar da tensão gerada da pela Lei Federal № 6.206, de 7 de maio de 1975, aspectos positivos são reconhecidos pelos profissionais da Capoeira.

Como aplicação prática, o estudo nos mostra que os entrevistados, em sua maioria, reconhecem a necessidade da formação e da informação da área do esporte para trabalhar com a Capoeira, sendo possível perspectivar a colaboração de profissionais da Educação Física com grupos de Capoeira na elaboração de programas de treinamento e estratégias de avaliação para graduações.

\section{Agradecimentos}

Agradeço ao Cnpq e aos membros pesquisadores do LAPEGI (Laboratório de Pesquisas e Experiências em Ginástica).

${ }^{1} \mathrm{ABIB}$, P. R. J. Os velhos capoeiras ensinam pegando na mão. Cadernos Cedes, v. 26, n. 68, p. 86-98, 2006.

BARDIN, L. Análise de conteúdo. São Paulo: SP : Edições 702011 , 2011. 